\title{
Schedule III Substance
}

National Cancer Institute

\section{Source}

National Cancer Institute. Schedule III Substance. NCI Thesaurus. Code C48676.

A category of drugs that have less potential for abuse or addiction than Schedule I or II drugs and have a useful medical purpose. 